\title{
POTENSI SUMBER DAYA DAERAH DAN KESEJAHTERAAN
}

\section{KELUARGA TKI}

Oleh:

Ida Nuraini (Staf Pengajar Fak. Ekonomi dan Bisnis-UMM) Arfida Boedi Rochminarni (Staf Pengajar Fak. Ekonomi dan Bisnis-UMM)

\begin{abstract}
The objective of this study was to investigate the local resource potential and migrant workers' family welfare. The data were analyzed through Structural Equation MODELING (sem) or so-called Linear Structural Equation (LISREL) to measure the connection of resources in the workers' origins and poverty. The results show that both human dan natural resources do not significantly affect the walfare of migrant workers' families. Hence, the Local Government (Regency) is expected to increase financeial resources such as banking institutions, cooperatives, savings and loan institutions, finance and so on, besides increasing the number of physical resources such as markets and roads.
\end{abstract}

Keywords: Welfare, Migrant Workers, Remittance, Financial Resources.

\section{Abstrak}

Tujuan penelitian ini adalah untuk mengetahui potensi sumber daya daerah dan kesejahteraan keluarga TKI. Untuk mengukur sebesar apa peran sumber daya yang ada di daerah asal TKI terhadap masalah kemiskinan masyarakat, pada penelitian ini peneliti menganalisa data dengan menggunakan analisis Structural Equation Modelling (SEM) atau juga disebut Linier Structural Equation (LISREL). Hasil pengujian membuktikan bahwa Sumberdaya manusia dan sumberdaya alam tidak berpengaruh secara signifikan terhadap kesejahteraan keluarga TKI, dan yang berpengaruh signifikan terhadap kesejahteraan keluarga TKI adalah sumberdaya finansial dan sumberdaya fisik. Oleh sebab itu Pemerintah Daerah khususnya Kabupaten diharapkan dapat meningkatkan jumlah sumberdaya finansial seperti lembaga perbankan, koperasi, lembaga simpan pinjam, finance dan sebagainya. Disamping itu peningkatan jumlah sumberdaya fisik seperti pasar dan sarana jalan.

Kata Kunci : Kesejahteraan, TKI, Remittances, Sumberdaya finansial

\section{PENDAHULUAN}

Indonesia merupakan negara keempat terbesar dengan jumlah penduduk sekitar 226 juta jiwa, yang saat ini tumbuh sekitar 1,24 persen (2,8 juta jiwa) setiap tahunnya. Sejak 1995 hingga 2005 jumlah tenaga kerja meningkat sebesar 1,3 persen, rata-rata bertambah sebanyak 1,2 juta orang per tahun, namun dikarenakan krisis ekonomi, peningkatan tersebut tidak dapat diserap secara efektif dan angka resmi pengangguran 
meningkat dari 9,5 juta pada tahun 2003 menjadi 10,8 juta di tahun 2005 dan sekitar $11.5 \%$ pada tahun 2010 . Rendahnya penyerapan tenaga kerja di dalam negeri telah mendorong tenaga kerja untuk mencari dan memanfaatkan kesempatan kerja di luar negeri, karena tingkat upah yang ditawarkan biasanya lebih baik dibandingkan dengan upah pekerjaan sejenis di dalam negeri.

Pemerintah

mulai

mempromosikan tenaga kerja migran di tahun 1990an dan pada tahun 2010, telah mencapai peningkatan hingga 712.160 orang. Dengan perbandingan jumlah wanita dalam jumlah tersebut pada tahun 2010 adalah 75,3 persen. Pengiriman sekitar 3,9 juta tenaga kerja antara 1996 dan 2010 sama besarnya dengan lebih dari sepertiga pertumbuhan tenaga kerja berusia 15 hingga 39 tahun selama masa tersebut. Dilihat dari negara tujuan, maka negara tujuan yang paling diinginkan oleh migran internasional Indonesia adalah Malaysia, kemudian Arab Saudi.

Jika ditinjau dari jumlah tenaga kerja migran berdasarkan daerah asal, Tabel 1 memperlihatkan bahwa tenaga kerja migran internasional terbesar berasal dari Pulau Jawa, kemudian disusul oleh Kalimantan dan Sumatera. Tetapi jika dilihat dari pertumbuhannya selama periode 1985 hingga 2005, peningkatan pengiriman jumlah migran internasional terbesar berasal dari Sumatera, dengan persentase pertumbuhannya sebesar 23.18 persen.

$\begin{array}{ccc} & \text { Pengiriman tenaga kerja } \\ \text { migran } & \text { internasional akan }\end{array}$
memberikan sumbangan devisa yang besar bagi negara melalui remittances yang dikirimkan tenaga kerja tersebut kepada keluarganya. Berdasarkan Tabel 1 diperlihatkan bahwa selama periode 1985-2005, peningkatan jumlah migran internasional setiap pulau diikuti pula dengan meningkatnya jumlah penerimaan devisa pada masingmasing pulau tersebut. Jumlah sumbangan devisa tertinggi diperoleh dari kiriman remittances migran internasional asal Jawa, dimana pada tahun 2005, jumlah remittancess yang dikirim oleh migran asal Jawa 
sebesar 1.7 milyar US dollar yang diperoleh dari 277.458 orang migran.

Meskipun

negara

diuntungkan dari adanya TKI di luar negeri melalui penerimaan devisa, namun bukan berarti pengiriman TKI keluar negeri tidak menyisakan masalah. Setidaknya ada dua permasalahan pokok pengengiriman TKI keluar negeri, yaitu: Pertama, masih banyaknya TKI yang terlantar akibat penganiayaan yang disebabkan karena perlindungan belum optimal dari pihak Pemerintah Indonesia. Kedua, belum dirasakannya dampak yang berkelanjutan dari hasil TKI yang sukses bekerja di luar negeri. Kebanyak dari mereka akan kembali menjadi miskin ketika pulang ke kampung halamanya. Kondisi ini disebabkan karena pola konsumtif dan belum adanya bentuk pemberdayaan TKI yang dilakukan oleh pemerintah pasca mereka pulang dari bekerja di luar negeri.

Tinginya konsumerisme wanita atau $i b u$ rumah tangga menurut hasil penelitian Arfida BR. (2002) disebabkan karena gaya hidup, lingkungan sosial, dan tingkat pendapatan. Karena gaya hidup dan lingkungan sosial yang metropolis dimana TKI bekerja dan ditunjang dengan pendapatan yang relatif besar, maka mereka cenderung untuk menghabiskan pendapatannya unuk hal-hal yang bersifat konsumtif ketimbang untuk modal usaha.

Sejalan dengan permasalahan di atas maka penting dibangunnya sebuah model pemberdayaan dengan pendekatan kesejahteraan ekonomi yang berkelanjutan (Sustainable Livelihood Approach) terhadap mantan Tenaga Kerja Indonesia (TKI). Model ini akan mengoptimalkan pendapatan yang relatif besar atau remittance dari TKI untuk mengembangkan potensi lokal yang ada di daerah asalnya. Untuk itu diperlukan langkah-langkah dalam merumuskan model pemberdayaan TKI. Langkah tersebut diantaranya adalah dengan mengidentifikasi potensi ekonomi yang ada di daerah asal, yang bisa menjadi peluang usaha TKI untuk menjaga keberlangsungan kesejahteraan mereka, 
Tabel 1. Jumlah Tenaga Kerja Migran Internasional Menurut Pulau dan Negara Tujuan

\begin{tabular}{|c|c|c|c|c|c|c|c|}
\hline \multirow[t]{2}{*}{ Pulau } & \multirow[t]{2}{*}{ Tahun } & \multicolumn{6}{|c|}{ Negara Tujuan } \\
\hline & & $\begin{array}{c}\text { Malaysia } \\
\text { (Orang) }\end{array}$ & $\begin{array}{c}\text { Singapura } \\
\text { (Orang) }\end{array}$ & $\begin{array}{c}\text { Hongkong } \\
\text { (Orang) }\end{array}$ & $\begin{array}{c}\text { Arab } \\
\text { Saudi } \\
\text { (Orang) }\end{array}$ & $\begin{array}{c}\text { Negara } \\
\text { Lain } \\
\text { (Orang) }\end{array}$ & $\begin{array}{c}\text { Total } \\
\text { (Orang) }\end{array}$ \\
\hline \multirow[t]{6}{*}{ Sumatera } & 1985 & 306 & 286 & 60 & 46 & 41 & 739 \\
\hline & 1990 & 5772 & 1528 & 135 & 40 & 800 & 8275 \\
\hline & 1995 & 4719 & 4536 & 766 & 42 & 2838 & 12901 \\
\hline & 2000 & 37838 & 5074 & 4285 & 110 & 10989 & 58296 \\
\hline & 2005 & 39848 & 4952 & 2397 & 145 & 11508 & 58850 \\
\hline & $\mathbf{r}(\%)$ & 26.10 & 14.54 & 19.20 & 5.62 & 30.79 & 23.18 \\
\hline \multirow[t]{6}{*}{ Jawa } & 1985 & 576 & 541 & 113 & 45080 & 2743 & 49053 \\
\hline & 1990 & 10893 & 2884 & 254 & 39051 & 5685 & 58767 \\
\hline & 1995 & 8907 & 8561 & 1445 & 40986 & 5685 & 65584 \\
\hline & 2000 & 71413 & 9576 & 8087 & 107424 & 45646 & 242147 \\
\hline & 2005 & 75208 & 9346 & 4524 & 141486 & 46895 & 277458 \\
\hline & $\mathbf{r}(\%)$ & 26.11 & 14.53 & 19.21 & 5.60 & 14.47 & 8.60 \\
\hline \multirow[t]{6}{*}{ Kalimantan } & 1985 & 449 & 421 & 88 & 161 & 66 & 1185 \\
\hline & 1990 & 8481 & 2246 & 198 & 140 & 1185 & 12250 \\
\hline & 1995 & 6936 & 6666 & 1125 & 147 & 4195 & 19069 \\
\hline & 2000 & 55606 & 7457 & 6297 & 384 & 16202 & 85946 \\
\hline & 2005 & 58561 & 7277 & 3522 & 506 & 16965 & 86831 \\
\hline & $\mathbf{r}(\%)$ & 26.10 & 14.53 & 19.21 & 5.60 & 30.25 & 22.69 \\
\hline \multirow[t]{6}{*}{ Sulawesi } & 1985 & 7 & 7 & 1 & 35 & 3 & 53 \\
\hline & 1990 & 130 & 34 & 3 & 31 & 21 & 219 \\
\hline & 1995 & 107 & 102 & 17 & 32 & 73 & 331 \\
\hline & 2000 & 854 & 114 & 97 & 84 & 267 & 1416 \\
\hline & 2005 & 899 & 112 & 54 & 110 & 279 & 1454 \\
\hline & $\mathbf{r}(\%)$ & 26.01 & 14.11 & 20.92 & 5.60 & 24.09 & 17.08 \\
\hline \multirow[t]{6}{*}{ Pulau Lain } & 1985 & 210 & 197 & 41 & 2545 & 177 & 3170 \\
\hline & 1990 & 3964 & 1050 & 92 & 2205 & 787 & 8098 \\
\hline & 1995 & 3241 & 3116 & 526 & 2314 & 2594 & 11791 \\
\hline & 2000 & 25990 & 3485 & 2943 & 6065 & 8939 & 47422 \\
\hline & 2005 & 27371 & 3401 & 1646 & 7988 & 9311 & 49717 \\
\hline & $\mathbf{r}(\%)$ & 26.10 & 14.53 & 19.22 & 5.60 & 20.77 & 14.01 \\
\hline \multirow[t]{6}{*}{ Indonesia } & 1985 & 1547 & 1451 & 304 & 47867 & 3031 & 54200 \\
\hline & 1990 & 29240 & 7743 & 681 & 41466 & 8475 & 87605 \\
\hline & 1995 & 23909 & 22982 & 3878 & 43521 & 26596 & 120886 \\
\hline & 2000 & 191700 & 25707 & 21709 & 114067 & 82043 & 435226 \\
\hline & 2005 & 201887 & 25087 & 12143 & 150235 & 84958 & 474310 \\
\hline & $\mathbf{r}(\%)$ & 26.11 & 14.54 & 19.20 & 5.60 & 17.20 & 10.88 \\
\hline
\end{tabular}

Keterangan $: r$ adalah rata-rata pertumbuhan migran pertahun

Sumber : Badan Pusat Statistik (diolah)

potensi lain yang ada di daerah asal, seperti fasilitas fisik, finansial, modal sosial, dan infrastruktur terhadap peluang usaha TKI yang akan dilakukan. Menganalisis bagaimana pengaruh faktor budaya yang terdiri dari: nilai-nilai tradisi dan gaya hidup di tempat kerja TKI terhadap perubahan pola konsumsi mereka di dalam negeri? Menganalisis bagaimana pengaruh faktor sosial yang terdiri dari: tingkat usia, julah anggota keluarga, dan tingkat pendidikan TKI terhadap pola konsumsinya? Dan menganalisis bagaimana pengaruh faktor ekonomi yang terdiri dari: penghasilan dan kekayaan TKI terhadap pola konsumsinya? 


\section{METODE PENELITIAN}

Daerah yang dipilih adalah Propinsi Jawa Timur mengingat banyaknya tenaga kerja yang bekerja di luar negeri berada di daerahdaerah yang tersebar di beberapa Kabupaten seperti Tulungagung, Malang. Kabupaten Tulungagung merupakan salah satu kabupaten terbesar dalam menghasilkan devisa dari pengiriman tenaga kerja ke luar negeri.

Responden yang digunakan adalah mantan tenaga kerja yang telah berpengalaman bekerja diluar negeri terutama dari Arab Saudi dan negara-negara ASEAN seperti Malaysia, Singapura, Taiwan, Korea Selatan dan lain-lain. Metode pengambilan sampel dilakukan dengan melakukan incidental sampling artinya pengambilan sample yang dilakukan terhadap setiap responden yang ditemui. Metode sampling tersebut tidak akan mengurangi tingkat representativeness mengingat variasi data dari masing-masing responden untuk masing-masing negara relatif homogen.
Data yang digunakan dalam penelitian ini adalah data primer yang berupa data penampang lintang (cross sectional data). Data tersebut diperoleh dengan cara melakukan wawancara yang mendalam (in-depth interview) terhadap mantan tenaga kerja baik TKI maupun TKW atau yang kebetulan berlibur (mudik) baik dalam rangka hari raya maupun yang sedang cuti sebelum memperpanjang masa kontraknya. Disamping itu data juga dikumpulkan dari para informan seperti tokoh masyarakat dan calo (broker) untuk mengidentifikasi peluang dan kendala dalam pengiriman tenaga kerja ke luar negeri. Jumlah responden yang dibutuhkan sebanyak 1000 orang untuk tenaga kerja dan 15 organisasi pengirim (PJTKI).

Teknik pengumpulan data yang dipakai adalah wawancara mendalam (in-depth interview), pengamatan terlibat terhadap mantan tenaga kerja atau tenaga kerja yang sedang berlibur. Data sekunder dapat diperoleh dari organisasi pengirim (PJTKI) dan dari Departemen Tenaga Kerja. Untuk mempertajam data yang diperoleh 
juga digunakan metode diskusi kelompok secara terfokus (focus group dicussion) dan pembuatan peta mekanisme pengiriman tenaga kerja ke luar negeri baik yang legal maupun ilegal.

Untuk mengukur sebesar apa peran sumber daya yang ada di daerah asal TKI terhadap masalah kemiskinan masyarakat, pada penelitian ini peneliti menganalisa data dengan menggunakan analisis Structural Equation Modelling (SEM) atau juga disebut Linier Structural Equation (LISREL).
Adapun langkah-langkah yang ditempuh dalam SEM adalah: 1) Pengembangan model berbasis konsep dan teori; 2) Mengkonstruksi diagram path; 3) Konversi diagram path ke dalam model structural; 4) Memilih matriks input; 5) Menilai masalah identifikasi; 6) Evaluasi goodness of fit; 7) Interpretasi dan modifikasi model.

Kerangka berfikir yang diajukan penulis sehubungan dengan permasalahan yang diteliti adalah sebagai

berikut:

Gambar. 1 Model Hubungan antara Variabel Independen dan Dependen-Variabel

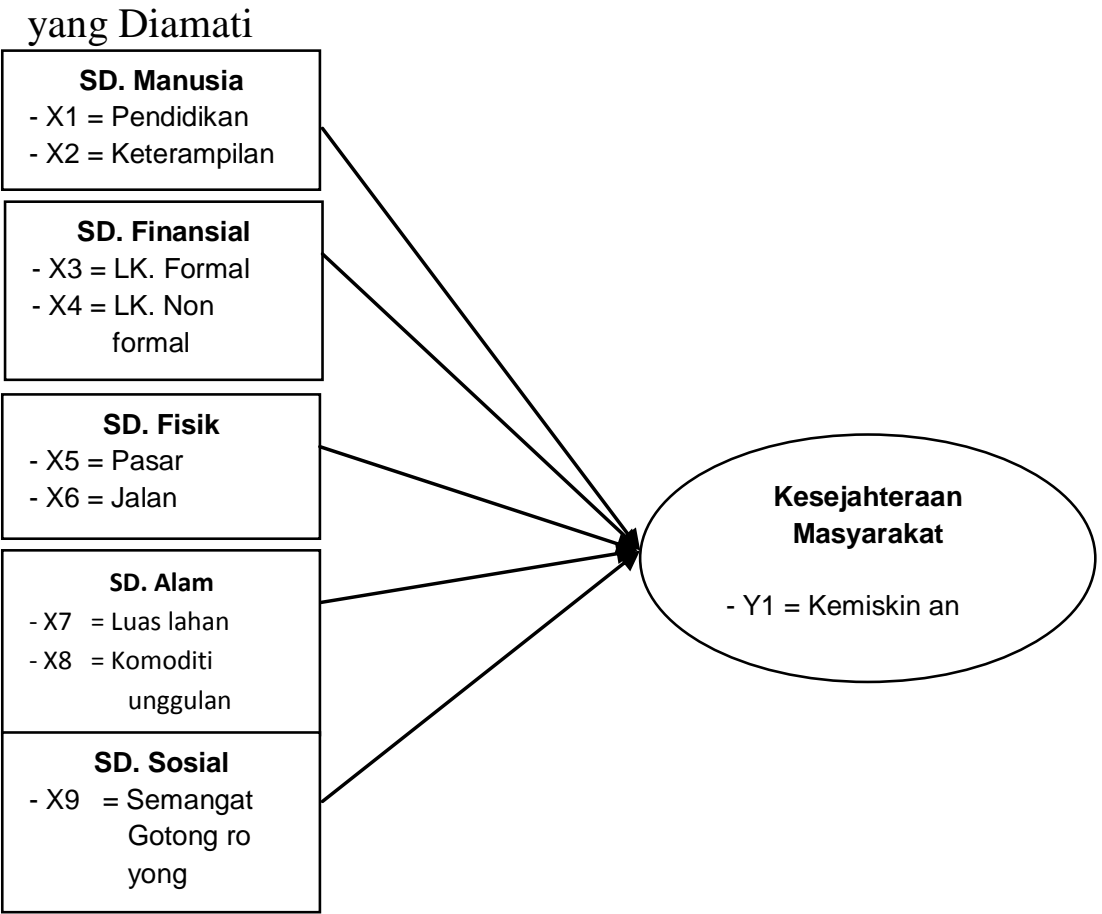


Adapun variabel yang digunakan peneliti terdapat 2 variabel, yaitu: pertama, Variabel bebas (independen variable) terdiri atas: 1) Sumberdaya manusia, indikatornya $\mathrm{X} 1=$ Pendidikan dan $\mathrm{X} 2$ = Keterampilan; 2) Sumberdaya finansial, indikatornya X3= Lembaga keuangan formal dan $\mathrm{X} 4=$ Lembaga keuangan non formal; 3) Sumberdaya fisik, indikatornya $\mathrm{X} 4=$ Pasar dan X5 = Jalan; 4) Sumberdaya alam, indikatornya X6 = Luas lahan pertanian dan $\mathrm{X} 7=$ Komoditi unggulan; 5) Sumberdaya sosial, indikatornya $\mathrm{X} 8=$ Semangat gotongroyong. Sedangkan Variabel tergantung (dependen variable) yaitu kesejateraan masyarakat, indikatornya $\mathrm{Y} 1=$ Kemiskinan dan $\mathrm{Y} 2=$ Pengangguran.

Langkah berikutnya yaitu konversi diagram path kedalam model matematika menjadi sebagai berikut:

$$
\begin{aligned}
& \mathrm{X}_{1}=\lambda_{1} . \xi_{1}+\delta_{1} \\
& \mathrm{X}_{2}=\lambda_{2} . \xi_{1}+\delta_{2} \\
& \mathrm{X}_{3}=\lambda_{3} . \xi_{2}+\delta_{3} \\
& \mathrm{X}_{4}=\lambda_{4} . \xi_{2}+\delta_{4} \\
& \mathrm{X}_{5}=\lambda_{5} . \xi_{3}+\delta_{5} \\
& \mathrm{X}_{6}=\lambda_{6} . \xi_{3}+\delta_{6} \\
& \mathrm{X}_{7}=\lambda_{7} . \xi_{4}+\delta_{7} \\
& \mathrm{X}_{8}=\lambda_{8} . \xi_{4}+\delta_{8}
\end{aligned}
$$

$\mathrm{Y}_{2}=\lambda_{14} \cdot \eta_{2}+\varepsilon_{2}$

$\mathrm{Y}_{1}=\lambda_{15} \cdot \eta_{1}+\varepsilon_{1}$

Responden yang digunakan adalah mantan tenaga kerja yang telah berpengalaman bekerja diluar negeri terutama dari Arab Saudi dan negara-negara ASEAN seperti Malaysia, Singapura, Taiwan, Korea Selatan dan lain-lain. Metode pengambilan sampel dilakukan dengan melakukan incidental sampling artinya pengambilan sample yang dilakukan terhadap setiap responden yang ditemui. Metode sampling tersebut tidak akan mengurangi tingkat representativeness mengingat variasi data dari masing-masing responden untuk masing-masing negara relatif homogen.

\section{PEMBAHASAN}

Kabupaten Tulungagung yang terdiri dari 19 Kecamatan pada dasarnya merupakan wilayah pertanian. Berdasarkan analisis Location Quotient (LQ) maka dapat diketahui sub sektor yang menjadi unggulan tiap-tiap kecamatan yang ada di Kabupaten Tulungagung. Untuk sub sektor tanaman bahan makan, perkebunan dan peternakan dapat dilihat pada gambar 1 . 
Gambar 2. Peta Kabupaten Tulungagung Berdasarkan Sub Sektor Tanaman Bahan Makanan, Perkebunan dan Peternakan



Kecamatan yang memiliki potensi sub sektor unggulan tanaman bahan makan adalah kecamatan Pagerwojo dengan tujuh komoditi unggulan yang dimiliki. Sedangkan untuk tanaman perkebunan dimiliki oleh kecamatan Tanggunggunung, Kec. Pucanglaban dan Kec. Gondang dengan masing-masing memiliki tiga komiditi unggulan. Sub sektor peternakan terbanyak dimiliki oleh Kecamatan Rejotangan dengan 10 komiditi unggulan. Gambaran selengkapnya dapat dilihat pada gambar 2,3 dan 4 .
Sementara itu untuk sub sektor industri kecil yang paling banyak mempunyai industri kecil unggulan adalah kecamatan Kedungwaru dengan tujuh industri unggulan dari delapan jenis industri kecil yang ada. Kecamatan Ngunut dengan 9 jenis industri kecil yang ada hanya ada enam jenis industri kecil yang unggul, demikian pula dengan kecamatan Tulungagung yang memiliki sembilan jenis industri kecil hanya ada enam jenis 
industri yang unggul. Adapun Namun secara garis besar dapat kecamatan Pagerwojo dan diketahui bahwa Kabupaten Kecamatan Tanggunggunung Tulungagung memiliki potensi pada memiliki jumlah industri kecil industri makanan dan minuman dan tersedikit yaitu empat jenis industri industri tembakau.

kecil dan semuanya bukan

merupakan industri kecil unggulan.

Gmbar 3: Peta Kabupaten Tulungagung Berdasar sub sector Industri

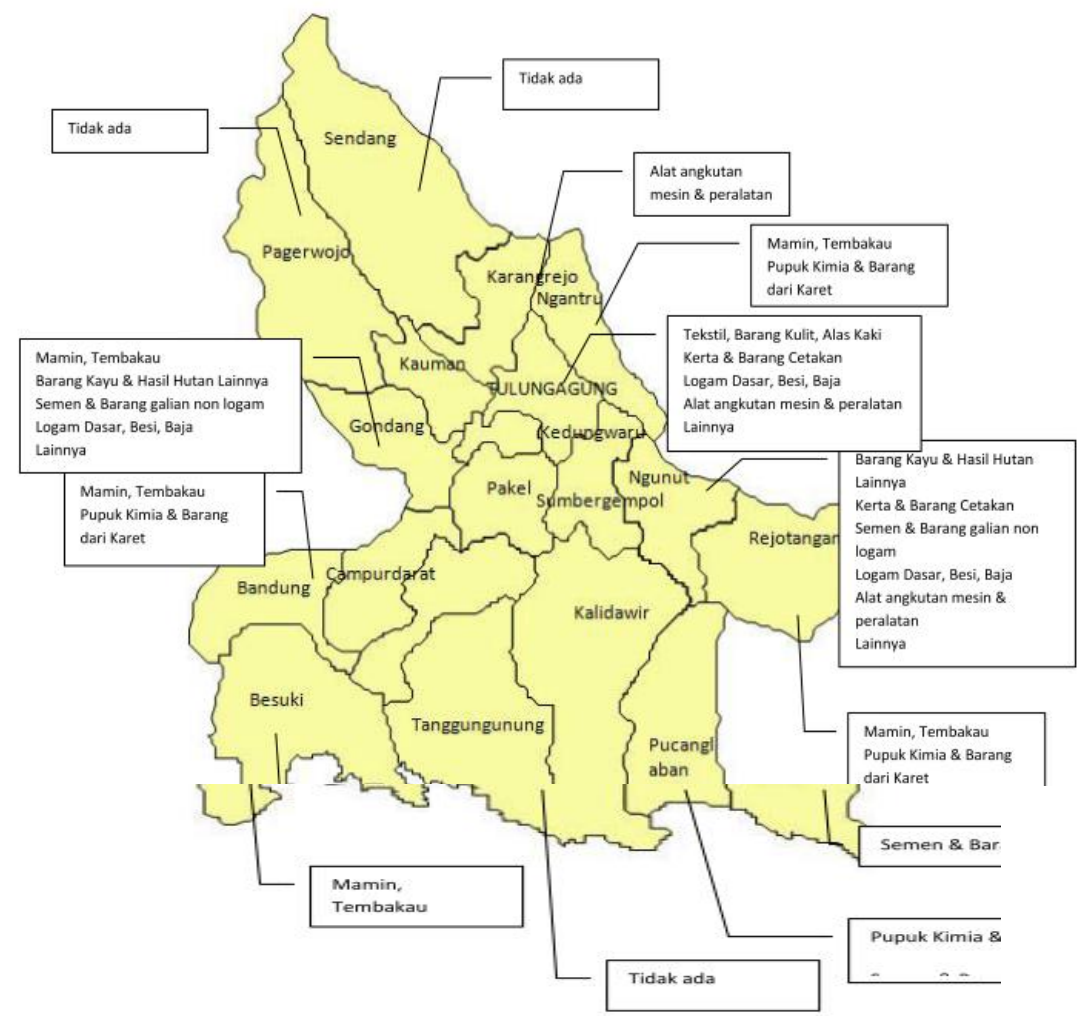


Gambar 4. Peta Kabupaten Tulungagung Berdasarkan Sub Sektor Industri Besar

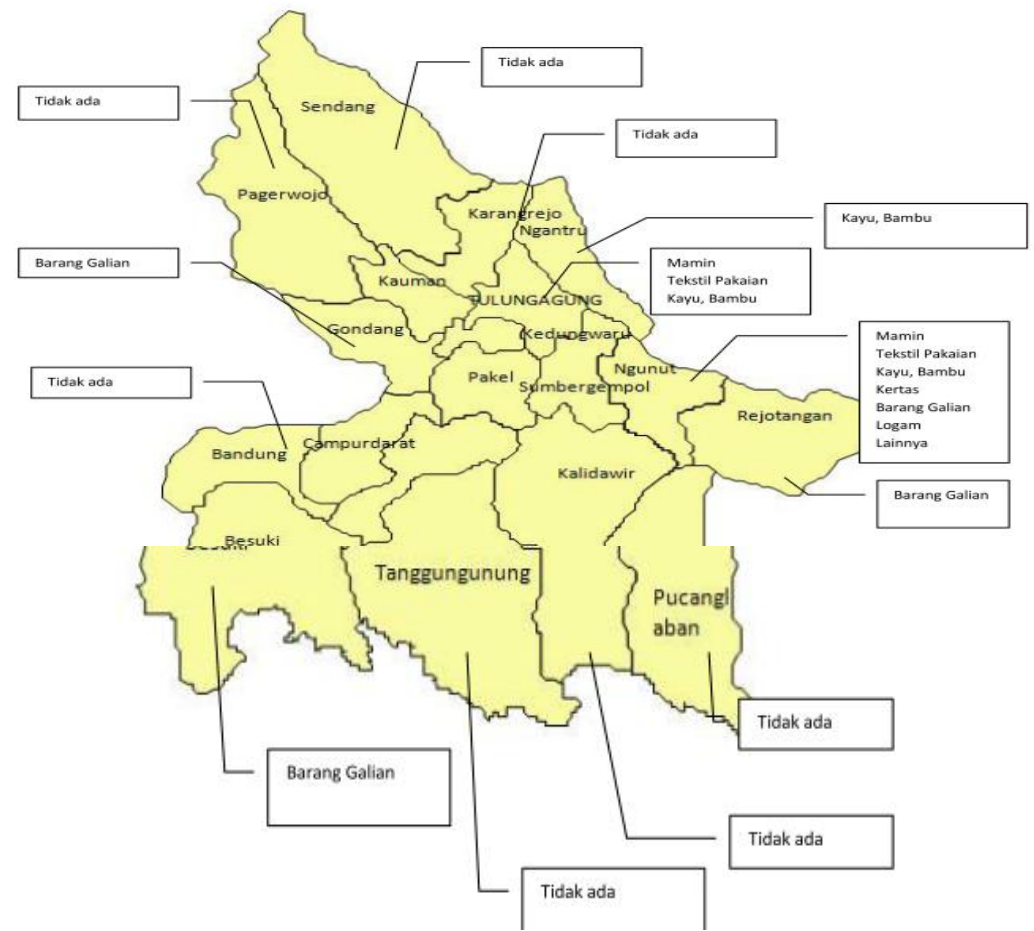

Industri besar banyak dimiliki keluarga TKI dan masyarakat pada oleh kecamatan Ngunut dengan tujuh umumnya dengan memanfaatkan jenis industri besar yang kesemuanya keunggulan wilayah masing-masing. merupakan industri unggulan, Keunggulan mutlak yang dimiliki sementara itu kecamatan yang tidak oleh suatu wilayah merupakan modal memiliki industri besar sama sekali dasar bagi berlangsungnya suatu adalah kecamatan, Bandung, transaksi atau perdagangan. Oleh Tanggunggunung, Kalidawir, sebab itu Pemerintah Daerah harus Pucanglaban, Karangrejo, Pagerwojo dan Sendang.

Dengan diketahuinya jenisjenis komoditi unggulan yang dimiliki oleh beberapa kecamatan yang ada di Kabupaten Tulungagung maka dapat dijadikan sebagai landasan untuk memulai menjalankan usaha khususnya bagi berperan aktif khususnya sebagai fasilitator dan motivator bagi masyarakat agar kegiatan ekonomi tumbuh berkembang sehingga berpengaruh pada peningkatan pendapatan masyarakat.

Sumberdaya manusia berupa pendidikan dan ketrampilan, Sumberdaya finansial berupa jumlah 
lembaga keuangan formal dan non formal, sumberdaya fisik berupa jumlah pasar dan panjang jalan, sumberdaya alam berupa luas lahan dan banyaknya komoditi unggulan serta sumberdaya sosial berupa semangat gotongroyong tidak semuanya berpengaruh secara signifikan terhadap tingkat kesejahteraan masyarakat yang diukur dari indikator jumlah kemiskinan dan pengangguran. Pengujian yang telah dilakukan menunjukkan hasil bahwa nilai koefisien untuk sumberdaya manusia sebesar 0,204. Akan tetapi, sumberdaya manusia di daerah asal TKI belum mampu mempengaruhi secara signifikan terhadap kesejahteraan masyarakat.

$$
\text { Untuk nilai koefisien }
$$
sumberdaya finansial sebesar 0,408. Sumberdaya finansial di daerah asal TKI terbukti mampu mempengaruhi secara signifikan terhadap kesejahteraan masyarakat. Hal ini berarti Semakin tinggi sumberdaya finansial di daerah asal TKI akan meningkatkan Kesejahteraan Masyarakat sekitar daerah asal TKI. Untuk nilai koefisien sumberdaya fisik sebesar 0,433 . Sumberdaya fisik di daerah asal TKI terbukti mampu mempengaruhi secara signifikan terhadap kesejahteraan masyarakat. Hal ini berarti Semakin tinggi sumberdaya Fisik di daerah asal TKI akan meningkatkan Kesejahteraan Masyarakat sekitar daerah asal TKI.

Untuk nilai koefisien sumberdaya alam sebesar -0,174. Akan tetapi, hasil ini tidak terbukti bahwa sumberdaya alam di daerah asal TKI mempengaruhi secara signifikan terhadap kesejahteraan masyarakat.

Untuk nilai koefisien sumberdaya sosial sebesar $-0,038$. Akan tetapi, hasil ini tidak terbukti bahwa sumberdaya sosial di daerah asal TKI mempengaruhi secara signifikan terhadap kesejahteraan masyarakat. 
Gambar. 5 Output

\begin{tabular}{|c|c|c|c|c|c|c|c|}
\hline \multirow{2}{*}{\multicolumn{8}{|c|}{ 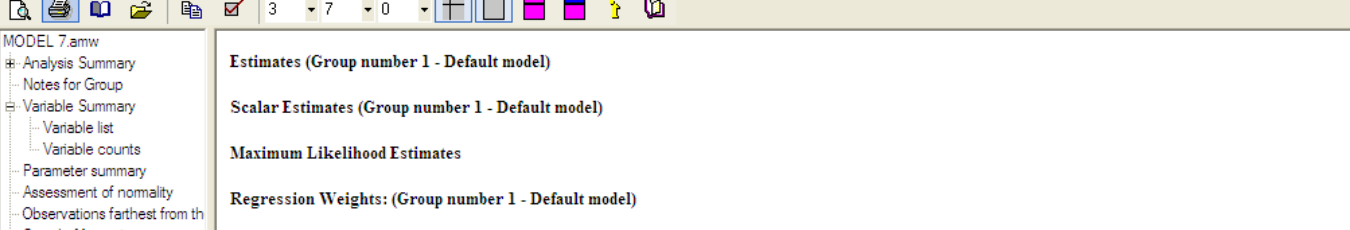 }} \\
\hline & & & & & & & \\
\hline $\begin{array}{l}\text { 1. Sample Moments } \\
\text { *-Notes for Model }\end{array}$ & & & Estimate & S.E. & C.R. & $\mathrm{P}$ & Label \\
\hline Estimates & KESEJAHTERAAN MASYARAKAT & <-- SUMBERDAYA FINANSIAL & .408 & .083 & 4.893 & $* * *$ & par 13 \\
\hline $\begin{array}{l}\text { to-Scalars } \\
\text { - Matrices }\end{array}$ & KESEJAHTERAAN_MASYARAKAT & <--- SUMBERDAYA_FISIK & .433 & .101 & 4.284 & $* * *$ & par_14 \\
\hline $\begin{array}{l}\text { क. - Matnines } \\
\text { +.- Modfication Indices }\end{array}$ & KESEJAHTERAAN MASYARAKAT & <-- SUMBERDAYA ALAM & -.174 & .083 & -2.086 & .037 & par 15 \\
\hline Minimization History & KESEJAHTERAAN MASYARAKAT & $<--$ SUMBERDAYA SOSIAL & -.038 & .069 & -.548 & .584 & par 16 \\
\hline $\begin{array}{l}\text { 4. Pairwise Parameter Comparis } \\
\text { +. Model Fit }\end{array}$ & KESEJAHTERAAN_MASYARAKAT & <--- SUMBERDAYA_MANUSIA & .204 & .091 & 2.235 & .025 & par_17 \\
\hline Execution Time & & <--- SUMBERDAYA_MANUSIA & 1.000 & & & & \\
\hline & $\mathrm{X} 2$ & <--- SUMBERDAYA_MANUSIA & 1.070 & .093 & 11.544 & $* * *$ & par_1 \\
\hline \multirow{7}{*}{$\leq \quad \leq$} & $\mathrm{X} 1$ & <--- SUMBERDAYA_MANUSIA & 1.072 & .093 & 11.502 & $* * *$ & par_2 \\
\hline & $\mathrm{X} 6$ & <--- SUMBERDAYA_FINANSIAL & 1.000 & & & & \\
\hline & $\mathrm{X} 5$ & <--- SUMBERDAYA_FINANSIAL & 1.079 & .076 & 14.175 & $* * *$ & par_3 \\
\hline & $\mathrm{X} 4$ & <--- SUMBERDAYA_FINANSIAL & 1.086 & .079 & 13.723 & $* * *$ & par_4 \\
\hline & $\mathrm{x} 9$ & <--- SUMBERDAYA_FISIK & 1.000 & & & & \\
\hline & $\mathrm{X} 8$ & <--- SUMBERDAYA_FISIK & 1.137 & .108 & 10.518 & $* * *$ & par_5 \\
\hline & $\mathrm{X} 7$ & <--- SUMBERDAYA_FISIK & 1.346 & .113 & 11.920 & $* * *$ & par_6 \\
\hline \multirow[t]{6}{*}{ Group number 1} & $\mathrm{X} 12$ & <--- SUMBERDAYA_ALAM & 1.000 & & & & \\
\hline & $\mathrm{X} 11$ & <--- SUMBERDAYA_ALAM & 1.109 & .110 & 10.088 & $* * *$ & par_7 \\
\hline & $\mathrm{X} 10$ & <--- SUMBERDAYA_ALAM & 1.365 & .125 & 10.956 & $* * *$ & par_8 \\
\hline & $\mathrm{X} 15$ & <--- SUMBERDAYA_SOSIAL & 1.000 & & & & \\
\hline & $\mathrm{X} 14$ & <--- SUMBERDAYA_SOSIAL & 1.078 & .088 & 12.321 & $* * *$ & par_9 \\
\hline & $\mathrm{X} 13$ & $<---$ SUMBERDAYA_SOSIAL & 1.072 & .086 & 12.499 & **** & par_10 \\
\hline \multirow[t]{3}{*}{ Default model } & Y1 & <--- KESEJAHTERAAN_MASYARAKAT & 1.000 & & & & \\
\hline & Y2 & <--- KESEJAHTERAAN_MASYARAKAT & .853 & .078 & 10.864 & $* * *$ & par_11 \\
\hline & Y3 & <--- KESEJAHTERAAN_MASYARAKAT & .829 & .089 & 9.286 & $* * *$ & par_12 \\
\hline
\end{tabular}

Gambar. 6 Output

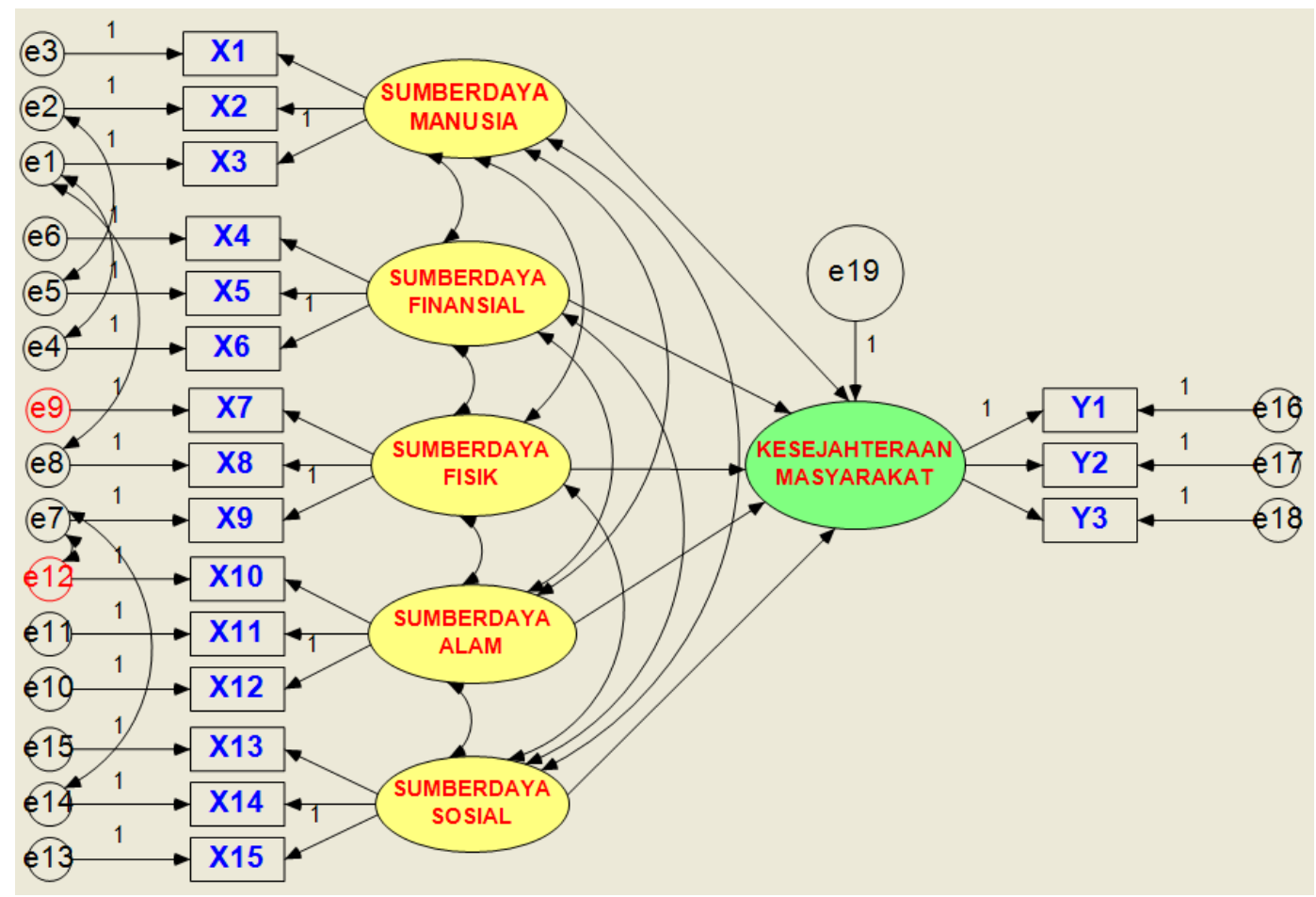

Pendapatan TKI yang dari tinggi dibandingkan dengan hasil kerja di uar negeri relative lebih pendapatan dari hasil kerja di dalam 
negeri, kondisi itulah yang gambaran penggunaan pendapatan menyebabkan mengapa TKI mau TKI dari bekerja di Luar Negeri. berkeja di luar negeri. Berikut ini

Tabel 2. Penggunaan Pendapatan Tenaga Kerja Indonesia (TKI)

\begin{tabular}{clc}
\hline No & Penggunaan Pendapatan TKI & Prosentase \\
\hline 1 & Beli / Rehap Rumah & 5.00 \\
2 & Beli Sepeda Motor/Mobil & 5.00 \\
3 & Modal Usaha & 37.50 \\
4 & Beli Tanah & 5.00 \\
5 & Biaya Pendidikan & 10.00 \\
6 & Lain-Lain & 37.50 \\
\hline
\end{tabular}

Berdasarkan data tabel 2. lain. Berikut ini beberapa kendala menunjukkan bahwa, sebesar yang sering dihadapi para mantan $37,50 \%$ pendapatan TKI adalah TKI dalam menjalankan atau untuk modal usaha dan $37,5 \%$ untuk memulai usahanya. keperluan lain-

Tabel 3. Kendala TKI Dalam Menjalankan Usaha

\begin{tabular}{clc}
\hline No & Kendala Menjalankan Usaha & Prosentase \\
\hline 1 & Modal Usaha & 24.32 \\
2 & Keahlian Manajerial & 24.32 \\
3 & Jiwa Interpreneur rendah & 5.41 \\
4 & Tenaga Ahli & 10.81 \\
5 & Informasi / Jaringan bisnis & 24.32 \\
6 & Lain-lain & 10.81 \\
\hline
\end{tabular}

Berdasarkan hasil analisis data tabel 3, menunjukkan bahwa kendala paling besar yang dihadapi oleh para mantan TKI dalam mengembangkan usaha atau memulai usahanya adalah modal usaha, informasi/jaringan bisnis dan keahlian manajerial. Ketiga masalah tersebut memiliki proporsi yang sama yaitu $24.32 \%$. sedangkan kendala yang paling rendah yang dihadapi adalah masalah jiwa interpreneur rendah.

Permodalan, keahlian, dan informasi bisnis memang menjadi permasalahan hampir disemua unit- 
unit usaha kecil termasuk yang kelangsungan usaha mereka terjaga, dihadapi para TKI yang menjalankan mengingat potensi-potensi bisnis di usaha di Kabupaten Malang dan daerah mereka sangat besar. Berikut Tulungagung. Permasalahan ini ini potensi pasar binis yang mereka tentunya harus diatasi agar tekuni selama ini.

\begin{tabular}{clc}
\multicolumn{2}{c}{ Tabel } & Potensi Pasar Komoditi Lokal Yang Menjadi Usaha TKI \\
\hline No & Potensi Pasar Komoditi Lokal & Prosentase \\
\hline 1 & Pasar local & 55.56 \\
2 & Pasar regional & 13.89 \\
3 & Pasar nasional & 16.67 \\
4 & Pasar Internasional/ekspor & 13.89 \\
\hline
\end{tabular}

Meskipun sebagian besar sudah menembus pasar internasional potensi lokal yang menjadi bisnis seperti kerajinan batu alam/onix di atau unit usaha TKI masih sebagian Kabupaten Tulungagung, Kerajinan besar bersifat lokal, namun ada grabah dari Kabupaten Malang. komoditi di sekitar mereka yang

Mengingat besarnya potensi mereka mengalami kemandekan ekonomi local di sekitar mantan TKI, usaha, maka sebagian besar dari maka kendala-kendala di atas harus mereka akan kembali menjadi TKI diatasi guna kelangsungan usaha dan lagi. Berikut ini jenis bantuan yang penghasilan para mantan TKI. Hal diinginkan dalam uapa meningkatkan ini menjadi penting karena jika usahanya.

Tabel 5. Bantuan yang Diinginkan TKI dalam Mengembangkan Usahanya

\begin{tabular}{clc}
\hline No & \multicolumn{1}{c}{$\begin{array}{c}\text { Bantuan yang diinginkan Untuk } \\
\text { Mengembangkan Usaha TKI }\end{array}$} & Prosentase \\
\hline 1 & Modal & 71.43 \\
2 & Pupuk dan Bibit & 0.00 \\
3 & Pelatihan kewirausahaan & 22.86 \\
4 & Informasi Pasar & 5.71 \\
\hline
\end{tabular}


Berdasarkan hasil analisis pada data tabel 5 menunjukkan bahwa, bantuan yang paling diinginkan oleh para TKI dalam upaya meningkatkan usahanya adalah bantuan modal, hal ini sama dengan permasalahan yang paling dirasakan juga masalah permodalan. Bantuan kedua yang paling diinginkan adalah pelatihan kewirausahaan, karena sebagian besar dari mereka lemah dalam manajerial usaha mereka.

\section{KESIMPULAN}

Permodalan, keahlian, dan informasi bisnis memang menjadi permasalahan yang dihadapi para TKI yang menjalankan usaha di Kabupaten Malang dan Tulungagung.

Meskipun sebagian besar potensi lokal yang menjadi bisnis atau unit usaha TKI, namun ada komoditi di sekitar mereka yang sudah menembus pasar internasional seperti kerajinan batu alam/onix di Kabupaten Tulungagung, Kerajinan grabah dari Kabupaten Malang. Bantuan yang paling diinginkan oleh para TKI dalam upaya meningkatkan usahanya adalah bantuan modal.

Sumberdaya manusia, sumberdaya alam dan sumberdaya sosial tidak berpengaruh terhadap kesejahteraan masyarakat di daerah TKI, sedangkan sumberdaya finansial dan sumberdaya fisik berpengaruh signifikan terhadap kesejahteraan masyarakat di daerah TKI.

Oleh sebab itu beberapa hal yang perlu direkomendasikan terhadap pemerintah daerah khususnya Bappeda dan Dinas Tenaga Kerja dan Transmigrasi adalah : pertama, Peningkatan sumberdaya finansial seperti penambahan jumlah lembaga keuangan baik formal maupun non formal di beberapa Kecamatan seperti Perbankan, Finance, Koperasi, Lembaga Simpan Pinjam dan lain-lain. Kedua, Peningkatan sumberdaya fisik seperti penambahan jumlah pasar, unit-unit ekonomi lainnya serta perbaikan dan penambahan jalan daerah.

Ketiga, Langkah kebijakan yang perlu juga dilakukan untuk mendukung sektor potensial adalah 
peningkatan dan pembenahan kualitas SDM melalui penyuluhan dan pelatihan untuk menciptakan tenaga kerja yang berkualitas. Keempat, Pemberdayaan dan pendampingan mantan BMI ini adalah sesuatu yang mutlak harus dilakukan dengan cara mengembangkan dan memanfaatkan potensi sumberdaya alam asal daerah itu dimana berada. Konsep Pengembangan model Pemberdayaan yang tepat dilakukan dengan membangun jaringan kerja (Networking) dengan komunitas mantan Buruh Migran Indonesia (BMI) yang ada di setiap kabupaten

\section{DAFTAR PUSTAKA}

Anselm Strauss, Juliet Corbin, 1990, Basic of Qualitative Research: Grounded Theory Proceduresand Techniques, London, New delhi, Sage Publication.

Basrowi, Sudikin, 2002, Metode Penelitian Kualitatif Perspektif Mikro, Surabaya, Insan Cendikia.

Berger, L. Peter, Mary Douglas, Michell Foucoult, and Jurgen Harbermas, 1987, Cultural Analysis, London and New York: Routledge and Kegan Kegan Paul.

Berger, L. Peter \& Thomas Luckmann, 1994, Tafsir Sosial Antar Kenyataan, terjemahan Hasan dan membuka kembali jalur komunikasi dengan mantan majikan mereka dahulu.

Kelima, Globalisasi di dunia informasi saat ini memudahkan komunikasi yang dilakukan dengan menggunakan FB (Face Book) dan Email dengan media Website atau Portal dan Blogger. Pengembangan ICT (Informatica Community Technology), yang berbasis komunitas mantan BMI adalah menjadi jalan untuk pemberdayaan dan pendampingan untuk mengembangkan usaha mikro produktif yang dilakukan baik untuk jangka panjang dan pendek.

Basri dari The Social Construction of Reality: A Treatise in the Sociology of Knowledge, Jakarta: LP3ES.

Burhan Bungin, 2007, Penelitian Kualitatif: Komunikasi, Ekonomi, Kebijakan Publik, dan Ilmu Sosial Lainnya, Jakarta, Prenada Media Group.

2007, Metodologi Penelitian Kualitatif: Aktualisasi Metodologis ke Arah Ragam Varian Kontemporer, Jakarta, Raja Grafindo Persada.

Campbell, Tom, 1994, Seven Theories of Human Society, alih bahasa Budi Hardiman, Tujuh Teori Sosial: 
Sketsa, Penilaian, dan Perbandingan, Yogyakarta: Kanisius.

Collin, Finn, 1997, Social Reality, USA and Canada: Routledge Simuktaneously Published

Craib, Ian, 1986, Teori-teori Sosial Modern: Dari Parson sampai Habermas, Jakarta: Rajawali Press.

Ferguson, Harvie, 2001, Phenomenology and Social Theory, dalam George Ritzer and Bary Smart, ed. Handbook of Social Theory, London, California, New Delhi: Sage Publications Ltd.

Gregory Mankiw, 2001, Teori Makro Ekonomi, Jakarta, Erlangga

Lexy J. Moleong, 1998, Metode Penelitian Kualitatif, edisi Revisi, Bandung, Remaja Rosdakarya.

Maulani, Z. A. 2002, Zionisme: Gerakan Menaklukkan Dunia, Jakarta, Daseta.

Mohammad Miftahul Hidayat, "Teori Konsumsi Berorientasi Teologis Etis", Tesis, Yogyakarta: Magister Studi Islam UII, 2000.

Waters, Malcolm, 1994, Modern Sociological Theory, London, Thousand Oaks, London: Sage Publications.

Sayed Nawab Haidar Naqfi, Etika dan Ilmu Ekonomi, suatu Sintesis Islami, Bandung: Mizan, 1985.

Zenrif, M. F., 2006, Realitas dan Metode Penelitian Sosial dalam Perspektif al-Qur'an, Malang, UIN Malang Press.

Zeitlin, Irving M., 1998, Memahami Kembali Sosiologi: Kritik Terhadap Teori Sosiologi Kontemporer, Yogyakarta: Gadjah Mada University Press. 